trating major drug chains and the Internet. "None of the genetic tests now offered directly to consumers has undergone premarket review by FDA to ensure that the test results being provided to patients are accurate, reliable, and clinically meaningful."

The FDA recently warned 19 companies that it considers genetic tests as meeting "the statutory definition of a medical device," which would make them subject to full regulatory review. The FDA is also examining standardization of direct-to-consumer tests (www.cmaj.ca/cgi/doi/10.1503 /cmaj.109-3669).
In Ottawa, Health Canada is taking a far more relaxed approach. Personal test kits are "neither prohibited by law, nor subject to federal regulation," said spokesperson Christelle Legault in an email.

But the department's stance is dramatically different - and far more cautious - with regard to genetic tests employed by drug developers. All devices intended to be used for pharmacogenetic testing "are classified as Class III medical devices and require a premarket scientific assessment of [their] safety and effectiveness," federal guidelines stipulate, (www.hc-sc.gc.ca/dhp- mps/brgtherap/applic-demande/guides /pharmaco/pharmaco_guid_ld-eng.php).

Such genetic testing devices must be licensed or authorized "if the test results are to be used for diagnostic purposes, patient management, or are to be submitted to Health Canada in support of a clinical trial application or drug submission" as the devices may have "a profound impact on the safety and effectiveness of the drug for which the assay/test is performed," the guidelines add. - Paul Christopher Webster, Toronto, Ont.

DOI:10.1503/cmaj.109-3686

\title{
Self-governance threatened, provincial association says
}

Previously published at www.cmaj.ca

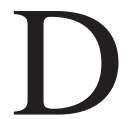
r. Rachel Kassner, president of the Medical Society of Prince Edward Island, is blunt and categorical in her assessment: "We, as physicians, really feel we've lost our self-governance."

Such powerful accusations are becoming the norm in a controversy that has physicians across the country turning their attention to Canada's smallest province and what may be precedent-setting bylaws that Island doctors say could limit their authority to self-regulate, muzzle their ability to speak out on health care issues and seriously constrain their ability to influence policy and service decisions in the health care system.

At issue is a set of proposed bylaws to govern Health PEI, the recently launched arm's-length organization that is responsible for delivering all Island health services.

Kassner says the "unacceptable" bylaws will diminish PEI's College of Physicians and Surgeons' authority to handle complaints against physicians by giving Health PEI the final say on disciplinary matters.

The bylaws will make Health PEI the judge of unethical and improper behaviour by doctors, says the Charlottetown family doctor. "All of the discipline has been put in the hands of the board of Health PEI."

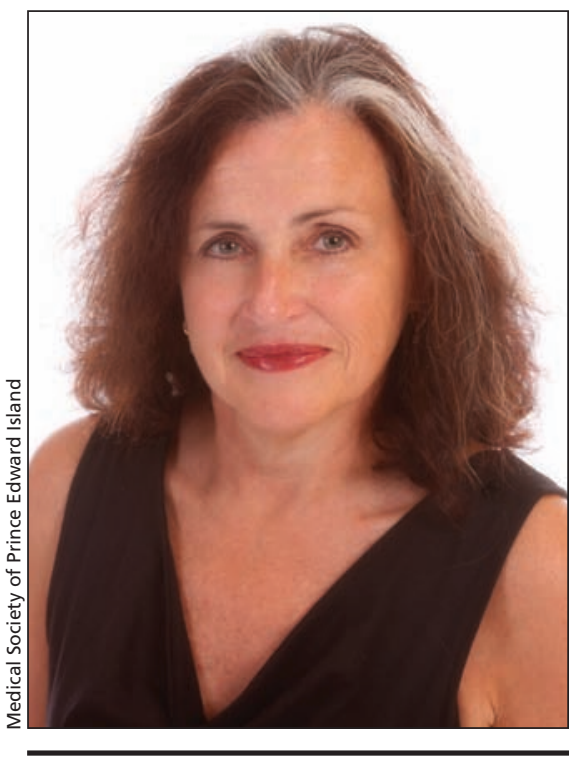

"A lot of us can't read the bylaws or understand them. You're totally overwhelmed," says Medical Society of Prince Edward Island President Dr. Rachel Kassner. "People are in shock."

Compounding the situation is that Health PEI's nine-person board cannot include anyone who earns money in the health care sector, a notion that doctors find irksome.

Kassner says the province's doctors are also concerned the bylaws will give Health PEI the power to punish physicians who speak out about systemic deficiencies. At the society's annual general meeting in September, doctors voted to seek legal advice on whether they can challenge the legitimacy of the bylaws.

But Dr. Richard Wedge, executive director of medical affairs for Health PEI and a past president of the medical society, says Island physicians need not fret.

The bylaws, he says, are intended to aid doctors by streamlining regulations and reducing paperwork. Moreover, they're a much-needed update, designed to replace decades-old sets of bylaws that now govern hospital practices.

And while the regulations define chains of command and procedures for handling complaints, they do not undermine professional self-regulation, he insists.

"Obviously we don't agree," with the criticism that a complaints review committee within Health PEI diminishes college authority, Wedge says. "The hospitals have all had disciplinary committees in the past and that's going to continue," he says, adding that the college will continue to have the final say on licensing and disciplinary matters.

As for silencing physicians, the bylaws provide specific avenues for doctors to voice concerns or advocate on behalf on patients, Wedge says. Doctors can bring their concerns to the medical director of their department, to their medical staff association, or express their opinions through the medical society.

Moreover, a Health PEI committee amended the draft bylaws in September to include a provision that secures a doctor's right to advocate on behalf of 
patients without penalty, Wedge adds. "If they advocate in an unprofessional or unethical manner, that's a different story. But if they advocate in an open, honest and transparent fashion - carry on. ... There's no gag order."

Wedge says the province continues to seek input on the bylaws, which was to be finalized in October, but adds that "we've already fixed all the concerns we know are out there."

The medical society, though, hasn't provided its formal response to the proposal and won't do so until it obtains legal advice and conducts a special meeting on Oct. 5. "A lot of us can't read the bylaws or understand them. You're totally overwhelmed," Kassner says. "People are in shock."

Compounding the angst is a July 6 report that the provincial government commissioned from Hay Group Health Care Consulting, which calls for a reduction in the number of family physicians in the province to 65 in 2015 from a current level of 90 . That would be offset by an increase in the number of consultants, such as internists, orthopedic surgeons and emergency room doctors.

The report also recommended an increase in interdisciplinary or teambased care, in which greater use is made of other health professionals to lessen the burden on doctors.

But Kassner argues the call for fewer family doctors and more team-based care is unrealistic as the province lacks the trained nurses, nurse practitioners and other health professionals to fill the void.

"People are really upset with that report. Most of us got really scared by it," Kassner says. "With the Hay report and the bylaws, it's very stressful here right now. It's a trying time to be a doctor on PEI.'

Wedge says the number of family doctor positions can only be trimmed if other support health professionals are first recruited. And the Hay recommendations, he notes, were similarly "draft" proposals. A final, revised version was expected in October.

He also argues the Island's health care system needs reform to improve the quality of care and lower the burden on doctors. - Quentin Casey, Halifax, NS

DOI:10.1503/cmaj.109-3687

\section{Preonar 13 Pneumococcal 13 -valent Conjugate Voccine (Diphtheria CRM Prip Protin)}

\section{Providing the broadest coverage of $S$. pneumoniae serotypes indicated in a pneumococcal conjugate vaccine ${ }^{-1,2,3}$}
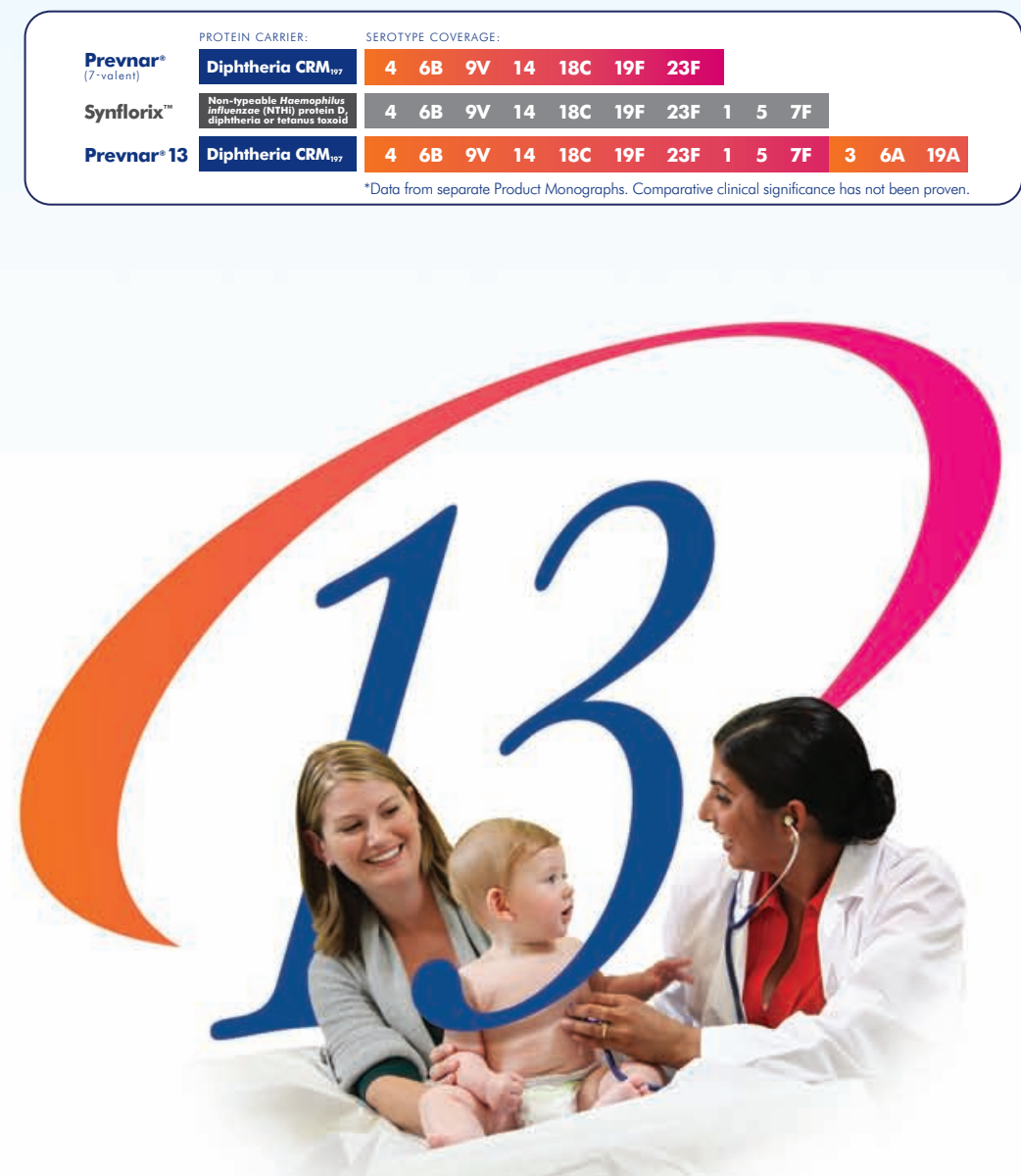

Wyeth $\stackrel{\text { Member }}{\text { RED }} \stackrel{\text { PAB* }}{\text { PA }}$

() 2010 Wyeth Canada

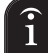

